\title{
THE NEXUS BETWEEN EXCHANGE RATE VARIATION AND ECO- NOMIC GROWTH IN NIGERIA
}

\author{
Ditimi Amassoma \\ Department of Economics and Development Studies, Federal University Oye-Ekiti, Nigeria \\ E-mail: amassoma.dit@gmail.com
}

Received October 2015; accepted August 2016

\begin{abstract}
s
This research paper is centered on the nexus between exchange rate variation and economic growth in Nigeria with emphasis to the purchasing power of the average Nigerians and the level of international transaction. Exchange rate fluctuations have been of serious concern to the monetary authorities, policy makers and business tycoons of developing countries, Nigeria inclusive because of the relevance of exchange rate in international trade, investment and in determining the level of output growth of a country. Therefore it is vital to examine the degree at which exchange rate fluctuates which had called for a lot of attention in Nigeria. This study examined the Impact of Exchange Rate Fluctuation on the Nigerian Economic Growth using an annual data of forty-three (43) years covering the period (19702013). The standard deviation method was employed to capture and estimate the fluctuation inherent in the model as regards the research's objective. The study employed econometric techniques such as; Multiple Regression Model, Augmented Dickey Fuller (ADF) test, Johansen Co-integration test and the Error Correction Model (ECM). Evidence from this study exhibited that there exists a positive but insignificant impact of exchange rate fluctuation on Nigerian economic growth in both the long run and short run. This result is attributed to the ability of the Nigerian government to effectively regulate some other important macroeconomic variables which can infuriate exchange rate which has thereby helped curtail the effects of exchange rate fluctuation during the study period. This is an indication that monetary authorities might have initiated policies that helped absorb the influence of exchange rate fluctuation on economic growth in Nigeria. Therefore, the government should encourage domestic production of goods and services for Naira exchange rate appreciation and generally to promote economic growth in Nigeria- moreover to maintain and sustain exchange rate and economic stability. In the same vein, the government should pay more attention to other more volatile macroeconomic variables like oil price and inflation rate in Nigeria.
\end{abstract}

\section{Research paper}

Keywords: Exchange Rate, Exchange rate fluctuation, Economic growth, Purchasing power, Macroeconomic variables

Reference to this paper should be made as follows: Amassoma, D. (2017). "The Nexus between Exchange Rate Variation and Economic Growth in Nigeria", Journal of Entrepreneurship, Business and Economics, Vol. 5, No. 1, pp. 1-40. 


\section{Introduction}

The role exchange rate plays in an economy cannot be undercut, this is because it directly affect all the macroeconomic variables such as: domestic price indicator, profitability of traded goods and services, allocation of resources and investment decisions, which in turn accounts for the reason why the monetary authorities and private sectors seeks to ensure the stability in these variables as opined by (Ajakaiye, 2001).

As a matter of fact, exchange rate fluctuations are now the bedrock for all economic activities globally, depicting adequate management of this variable as a major determinant of many countries economic policies as buttressed by (Todaro, 2004). Exchange rate is also an essential macroeconomic variable for formulating economic policies in general. This is owing to the extent to which these policies help accelerate the realization of set macroeconomic goals. For instance, in Nigeria, these objectives among others include achieving and upholding price stability, balance of payment equilibrium, full employment, even distribution of income, economic growth and development at large.

On the other hand, economic growth connotes a sustained increase in a country's national income according to (Jhingan, 1997). Expectedly, when the GNP of country rises eventually, it depicts a growth in the economy. Conversely, economic development refers to the structural and purposeful conversion of all the economic indicators from a low to a high level put by (Siyan, 2000)

As noted from the above, exchange rate fluctuation is the core of this current study, hence, it is described as the price of a country's currency in terms of that of another country's currency as buttressed by Fagbemi 
(2006). This rate is an exceptional price which government is interested in. For instance, evidence from the literatures, depicts that the choice of the right exchange rate or maintaining relative stability is essential for both internal and external balance and economic growth in the long run. While on the contrary, inefficient management of the exchange rate causes distortions in the patterns of consumption and production as opined by (Mordi, 2006). Notably, excessive fluctuation in exchange rate creates uncertainty and risks for economic agents with destabilizing effects on the macro-economy. No wonder, the private sector operators are concerned about the exchange rate fluctuations because of its impacts on their portfolios and may result in capital gains or losses according to (Mordi, 2006).

In line with the above, the study of Douglas and Jike (2005) noted that movements in the exchange rate are known to have ripple effect on other economic variables such as interest rate, inflation rate, unemployment rate, terms of trade, and so on. This claim was corroborated by Mordi (2006) where he pinpointed that exchange rate movements equally exerts effects on inflation, prices incentives, fiscal viability, exports competitiveness, efficiency in resource allocation, international confidence and balance of payments equilibrium. All of these factors underscore the importance of exchange rate to the economic wellbeing of every country that deals in the international trade of goods and services.

The Nigerian economy is characterized by structural severity and bottlenecks Nigeria's exchange rate policy has undergone substantial transformation from the immediate post-independence period when the country maintained a fixed parity with the British pound, through the oil boom of the 1970s, to the floating of the currency in 1986, following the near col- 
lapse of the economy between 1982 and 1985. In each of these eras, the economic and political considerations underpinning the exchange rate policy had important repercussions for the structural evolution of the economy, inflation, the balance of payments and real income. However, a major policy reversal was effected in September 1986 when the flexible exchange rate regime was put in place following the adoption of the SAP. During SAP, there was absence of foreign exchange allocation and import licensing procedures and transactions in foreign exchange were market based. This exchange rate regime helped solve the overvaluation of naira but devalued the naira. Exchange rate depreciation had since increase the naira price of imports and this is expected to discourage importation (Oyejide and Ogun, 1995).

The very year SAP commenced, exchange rate stood at N2.02:U.S $\$ 1.00$ but in 1987, 1990, 1991 it depreciated to an average of N4.02, N8.04 and N9.91 to US\$1.00 respectively. Again, in 1992 and 1993 it depreciated to N17.30 and N22.05: US\$1.00. In 1994, there was a need for the complete reversal of exchange rate policy due to the continuous depreciation of the exchange rate, thus with the re-introduction of a fixed exchange rate regime which made $\mathrm{N} 21.8861=\mathrm{US} \$ 1.00$. The dismal performance of the economy as at the end of 1994 led to the re-introduction of the market-based approach under the autonomous foreign exchange market (AFEM) from January 1995 until October 1999. The exchange rate which depreciated further from the fixed rate of N21.8881: US\$1.00 in 1994 to N81.00:US1.00 in 1995, and in less than a year after it was fixed to N84.38: US\$1.00 and N92.65:\$15\$1.00 in 1998 and 1999 respectively. It further depreciated to N128.75 between 2002 and 2005. However, Nigerian exchange 
rate was relatively stable in 2003 and between 2005 and 2008 Naira appreciated. The Naira -dollar exchange rate as at 2011 was 162.30 but fell to $\$ 156.15$ in 2012 and a further decline to 155.73 in 2013. The Naira-Dollar exchange value was highly volatile towards the end of 2014 and in 2015with 168 for 1USD, 204 for 1 USD in February 2015 but later reduced to 197 for 1USD as at August 2015 (Suraj et al, 2001).

In particular, the issue of exchange rate management and macroeconomic performance in developing countries has been a major concern among other economic policies. The debate focuses on the degree of fluctuations in the exchange rate in the face of internal and external shocks. There appears a consensus view on the fact that devaluation or depreciation could boost domestic production through stimulating the net export component. This is evident through the increase in international competitiveness of domestic industries leading to the diversion of spending from foreign goods whose prices become high, to domestic goods. Guitan (1976) and Dornbusch (1988) pinpointed the success of currency depreciation in promoting trade balance largely depends on switching demand in proper direction and amount as well as on the capacity of the home economy to meet the additional demand by supplying more goods. On the whole, exchange rate fluctuations are likely, in turn, to determine economic performance.

Exchange rate policies in developing countries are often sensitive and controversial, mainly because of the kind of structural transformation required, such as reducing imports or expanding non-oil exports, invariably imply a depreciation of the nominal exchange rate. Such domestic adjustments, due to their short-run impact on prices and demand, are perceived as damaging to the economy. Ironically, the distortions inherent in an overval- 
ued exchange rate regime are hardly a subject of debate in developing economies that are dependent on imports for production and consumption (Obadan, 2006).

In Nigeria, the exchange rate policy has undergone substantial transformation from the immediate. However, in spite of these different methods of determining exchange rate, a realistic exchange rate has not been found for naira because the existing exchange rate systems had continued to widen the gap between the official and the parallel markets and had failed to prevent disequilibrium in the foreign exchange market. It has also failed to ensure stability of the exchange rate as well as maintaining a favourable external reserve positions and consequently ensure external balances. In addition, the various exchange rate systems in used in Nigeria had also failed to eliminate or reduce the incidence of capital flight and the power to correct the sky rocketing Naira exchange rate has been missing. Therefore, what an unfavorable movement in exchange rates meant is a movement in current exchange rates away from mint parities in the direction of specie-export points. This is a lower exchange value for Nigeria and this has been perceived by Nigerians to be the most dominating economic problem of the country (Obadan, 1994)

Since there are conflicting (positive, neutral and negative) views on the impact exchange rate fluctuation has on economic growth. In light of the aforedetermined issue, this current study seeks to provide plausible answer to the underlying raised questions which includes: What are the causes of fluctuations of Nigeria's currency values? What has been the trend and pattern of Nigeria's exchange rate? How can exchange rate fluctuations be captured, estimated and predicted? What is the impact of exchange rate fluctua- 
tions on Nigerian economic growth? To what extent do exchange rate fluctuations affect Nigeria's economic growth?

Seemingly, the answers to the aforementioned questions will be the focal point of this study. Consequently, the main objective of this current study is to analyze the impact of exchange rate policies on gross domestic product and hence on the macroeconomic performance and development of the Nigerian economy with regards to the unstable nature of naira's exchange rate, the impacts on these macroeconomic variables depends solely on the prevailing economic conditions of a country at a point in time.

The remaining part of the paper would be structured as follow' section one comprises of the background to the study, statement of the problem, objectives of the study and so on. Section two, entails the review of related literature and theoretical framework. Section three presents the methodology and data sources, technique of analysis, while section four $\mathrm{x}$ ray the data analysis and discussion of results. Lastly, section five, concludes and proffer policy recommendations.

\section{Literature Review}

Exchange rate in Nigeria is an important macroeconomic variable in the economy today because of its significance in international trade, economic stability, external balance and competitiveness, which is done via the mechanism of the relative prices of foreign and local commodities, services and assets (Seyi,2012). In addition, exchange rate is an important economic measurement because it reflects the economic strength and competitiveness with other economies (Asinya and Takon, 2014; Akonji, 2013). 
Most importantly, a country's economic objectives are the strong factors in determining the exchange rate of such country. The strength of a country's currency depends on a number of factors. These include the state of the economy in terms of its competitiveness and volume of its exports, the level of domestic production, and the quantum of foreign reserves (CBN, 1999). Where the importation of essential goods and services becomes costly, as a result of increase in prices of domestic goods, the purchasing power of the domestic currency reduces- a depreciation of the domestic currency.

As a matter of fact, there exists a numerous body of theoretical and empirical research that suggested a more suitable exchange rate for developed and developing market economies (like Nigeria) and how exchange rate fluctuation affects Nigerian economic growth.

Furthermore, exchange rate variation exhibits pervasive impacts, with consequences for prices, wages, interest rates, level of production, and employment opportunities. After the Bretton Woods System collapsed, many countries have continued to witness incessant and ever increasing fluctuations in their exchange rates, particularly short term volatility has been on a crescendo sequel to the shift from fixed to flexible exchange rate in early 1970's and thereafter. High volatility and sudden changes in exchange rate is one of the obstacles for the success of macroeconomic policy. Forecasting nominal exchange rates is a difficult task especially in a flexible exchange rate arrangement according to (Rogoff, 2009).

In particular, factors affecting exchange rate can be economic, political, and psychological and can also be a short run or long run phenomenon. Specifically, it is worthwhile to note that the behaviour of exchange rate can 
be captured through macro variables and/or micro variables. Hence, academics, policy makers and monetary authorities are always looking for feasibly solutions to reduce the fluctuation in currencies values.

For instance, the early researches of some authors like Mundell's (1961) and McKinnon (1963) are of the view that economic size and openness are the fundamental determinants affecting a countries exchange regime of choice. He noted that small and open economies are more likely to adopt fixed exchange rates regime than large and relatively closed economies. Furthermore, Mohanty and Klau (2005) postulated that exchange rate is likely to assume special importance for monetary policy when the pass through of the exchange rate is high because it will affect real and financial sector directly and indirectly. On the other hand, some more recent studies confirm that the determinants of the choice of the exchange rate regime in transition economies should have into consideration the economic size and geographical concentration of trade as suggested by studies like (Markiewicz, A. 2006).Some researches extended the fundamental determinants and causes of exchange rate to be: integration into the international financial market, macroeconomic performance, the development of the financial sector, and political economy.

The Hooper-Morton's (1982) equilibrium real exchange-rate model is another approach to exchange rate determination. Frenkel (1976), based on the assumption of PPP, specified a model of the mark-dollar exchange rate during the German hyperinflation while Humphrey and Lawler (1977), using the standard monetary model investigated the behaviour of the USUK and US-Italy exchange rates, respectively. 
Particularly from the perspective of Nigeria, Osagie (1985) and Ajayi (1988) using the structuralist approach in their study of external trade flow, contrasts the adoption of a more flexible exchange rate policy in Nigeria. Ezirim and Muoghalu (2004) investigated the theoretical and empirical aspects of crisis and volatility in Nigeria.

Aydin (2010) observed different dynamics in the effect of macroeconomics fundamentals on the equilibrium real exchange rate of SubSaharan countries in his investigation on the impact of exchange rate volatility in 182 countries covering the period of 1973 to 2008

\section{Theoretical Framework}

Economists and financial experts are yet to agree on a single theory that defines the exchange rate. Hitherto, there are at least five competing theories of the exchange rate concept, which may either be classified as traditional or modern. The traditional theories are based on trade and financial flows, and purchasing power parity, and are important in explaining exchange rate movements in the long run.

These theories are: the elasticity approach to exchange rate determination, the monetary approach to exchange rate determination, the portfolio balance approach to exchange rate determination, and the purchasing power theory of exchange rate determination. The modern theory, however, focuses on the importance of capital and international capital flows, and hence, explains the short run volatility of the exchange rates and their tendency to overshoot in the long run.

Various studies, particularly, in the developed and middle-income countries, have also explored the impact of exchange rate volatility and as- 
sociated uncertainty on trade, investment, and economic growth. Majority of these studies have found that exchange rate volatility can affect trade directly, through uncertainty and adjustment costs, and indirectly through its effect on the structure of output and investment (Cote, 1994)

Aluko (1988), in his own view on the appreciation and depreciation of the naira since 1970 with regards to its effect on balance of payments and external reserves of the Nigeria, concluded that depreciation of the naira which he said was overvalued was necessary for the implementation of SAP. He did not however, consider the developing nature of the Nigerian economy. And as a developing economy, Nigeria mainly produces primary product and imports machinery and some (majors) raw materials for its industries. He did not consider the attendant high cost of imports which depreciation and devaluation would impose on such imports which would in turn, lead to high inflation rate. Kanyo (1988), in his work, blames competitive price floating exchange market. This he said is necessary due to the developing nature of the Nigerian economy.

Adamu (2005) researched on the impact of exchange-rate volatility on private investment and found a negative relationship between exchange rate volatility and private investment.

Eze (1988), in his appraisal of foreign exchange rate fluctuation on the Nigeria economy recommended that the central bank Nigeria should stabilize the value of Naira exchange at efficiently approved rate to the public. He however suggested what the government should influence in the foreign exchange rate, positive economy reforms that will reduce the adverse effects on unstable foreign exchange rate on the Nigeria economy. 


\section{The purchasing power parity}

The origin of purchasing power concept has been traced to the 16th century Salamanca School of Spain. During the nineteenth century, classical economists, like Ricardo, Mill, Goshen and Marshall endorsed and developed more or less qualified PPP views. The theory, in its modern form, is credited to Gustav Cassel, a Swedish economist, who developed and popularized its empirical version in the 1920s (Rogoff (1996). The nominal exchange rate should reflect the purchasing power of one currency against another and that a purchasing power exchange rate existed between any two countries which are measured by the reciprocal of one country's price level against another as opined by (Cassel (1916).

In furtherance, the central tenet of the PPP is that the equilibrium exchange rate is proportional to the relevant purchasing power parity of national currencies involved that is exchange rate fluctuations will destabilize the purchasing power of a country and hence impact significantly on investment and trade according to Aghevli (1991).

The condition for free trade is that the nominal exchange rate between two countries should be equal to the ratio of the price levels in the two countries (Taylor (1988).

This approach assumes that equilibrium real exchange rates remain constant over time and therefore, the nominal exchange rate movement tends to offset relative price movements.

The purchasing power theory parity theory defines two equilibrium rate systems. The first is the short run equilibrium exchange rate which is defined, in this context, as the rate that would exist under a purely freely floating exchange rate balance. Second is the long-run equilibrium that 
would yield balance of payment equilibrium over a time period in cooperating and cyclical fluctuations in the balance of payments (including those of prevailing exchange rate from the relative purchasing power in a currency are generally attributed to problem of arbitrage and expectations in the goods market. Some of the assumptions of PPP theory however are quite unrealistic and ambiguous, for instance the level of efficiency are different in countries as such there are deferring cost functions as buttressed by (Argy and Frenkel, 1978).

\section{The Traditional Flow Model}

The traditional flow model is also known as the balance of payment model. In this model, the exchange rate is in equilibrium when supply equals demand for foreign exchange, (Olisadebe, 1991:56). Exchange rates adjust to balance the demand for foreign exchange depends on the demand domestic residents have for domestic goods and assets. On the assumption that the foreign demands for domestic goods is determined essentially by domestic income, relative income plays a role in determined exchange rate under the flow model. Since assets demand can be said to demand on difference between domestic and foreign interest rates differential is other major determinants of the exchange rate in this frame work.

This theory stipulates that under free exchange rates, the exchange rate of the currency of a country depends upon its balance of payment. a favourable balance of payments raises the exchange rate, while an unfavourable balance of payments reduces the exchange rate (Jhingan,2004). Thus the theory implies that the exchange rate is determined by the demand for and supply of foreign exchange. 
The major limitation of the traditional model or the portfolio balance model is the over-shooting of the exchange rate target and the fact that substitutability between money and financial asset may not be automatic; this limitation triggered the emergence of the monetary approach. Consequently, this study employed the purchasing power parity and the traditional flow model because of the aforementioned assumption and justification.

\section{Empirical Evidences}

The empirical evidence of the impact of exchange rate fluctuation on economic growth has been pictured through the medium of trade in which the nature of the effect can either be positive or negative, the postulation of IMF (1984) and European commission (1990) empirical evidence in favour of a systematic positive (or negative) effect of exchange rate stability on trade (and thereby growth) in small open economies has remained mixes.

Evidently, the work of Bachetta and Van Wincoop (2000) found based on a general equilibrium framework that exchange rate stability on trade. Gravity models have been used as frame work to quantify the impact of exchange rate stability on trade and growth, in particular in the context of monetary union. On a similar basis, using panel estimations for more than 180 countries Edwards and Levy Yeyati (2003) found evidence that countries with more flexible exchange rate grow faster.

Furthermore, Edwards (1983) worked on the Peruvian experience with floating exchange rates by using a short-run version of the simple monetary model of exchange rate determination and found the results supportive, on the other hand, McNown \& Wallace (1989) and Baillie \& Selover (1987) using co integration found little or no back up for the monetary 
approach of exchange rate determination evidence for the monetary approach to exchange rate determination.

Eichengreen and Lablang (2003) found evidence of a significant negative relationship between the stability of and the growth of 12 countries over a period of 120 years. Based on their results, they concluded that such outcomes were influenced by the time period and the sample on the other hand; the study of Schnabel (2003) revealed that exchange rate stability is strongly associated with more growth in the EMU periphery. He further concluded that the evidence was strong for EMERGING Europe during the study period.

In Nigeria, in 1987 the budget and the rate of inflation have been encouraging. In her own view, the rate of inflation has been reasonably controlled though not reduced thoroughly. Notwithstanding attempts aimed at reducing prices, inadequate demand for the products of local industries is hampering their growth.

Chen (2004) analyzed the speed of convergence towards PPP in his research work on exchange rate volatility. He found a positive significant coefficient for exchange rate volatility, that is the higher the fluctuations in exchange rate, the stickier the prices are.

An empirical research conducted to investigate the links between exchange rates and macro-economic variables was based on the analytical framework developed by Kamin (1997) which showed evidence of an empirical relationship existing between exchange rate and the rate of in some selected Latin, Asian and advance industrialized countries.

Following the analytical framework provided by Kamin (1991), Morely (1992) had examined the impact of real exchange on the output for 
twenty-eight developing nations which were experiencing exchange rate devaluation, using a regression framework.

The study thus concluded that devaluation of exchange rate is a major factor for the upsurge inflation (Kamin 1996, Odedoolkun, 1996, Lane and Green (1991).

Kamin (1996) showed that the level of rate of inflation in Mexico during the 1980's and 1990s. Canetic and Greene (1991), Falokun (1994) reached similar conclusions for some African countries including Nigeria. However, using static applied general equilibrium (first generation), Boadiary and Trendenick (1978), found that removing tariff in Canada would bring about a fall in welfare to decline by inducing unfavourable trade, resulting from an import tariff reduction, this made Broom (1987) conclude that unilateral trade liberalization is essential.

Notably, Dell' Arricia (1999) examined the effect of exchange rate fluctuation on the bilateral trade of European Union members plus Switzerland over the period 1975 - 1994 using several definitions of volatility. In basic OLS regression, exchange rate fluctuation had a small but significant negative impact on trade; reducing volatility to zero in 1994 would have increased trade by an amount ranging from the ten to 13 percent, depending on the measures of fluctuation used using both fixed and random effects, the impact of fluctuation was still negative and significant but smaller in magnitude. The author found that elimination of exchange rate fluctuation would have increased trade by about 3 percent in 1994.

Moving to the studies of exchange rate volatility on trade in LDC'S Countries (1981) who used a log-level model specification to examine Brazilian exports, used annual data for 1965-1974 to arrive at the conclusion 
that a significant reduction in exchange rate uncertainty in Brazilian's economy during the crawling - peg era was adopted in 1968.

Phillips (1986), Granger and Newbold (1974) found that export and exchange rate risks are related, however, they criticize the use of a log-level model when the data is non-stationary.

In particular, the study of Osuntogun et al (1993) in their analysis of strategic issues in promoting Nigerian non-oil exports determined the effects of exchange uncertainty on Nigerian non-oil export performance as a side analysis. This is the pioneering effort in Nigeria to determine the effect of exchange rate risk on exports. However, their model did not take into consideration the cross price effects. Exchange rate acts as shock absorber if rigidly fixed, the shocks of inflation and deflation and deflation from aboard are transmitted to internal economy systems. But variations in the exchange can wand off the invasion of the inflationary and deflationary forces. The real exchange rate had a positive influence $(1.2 \%)$ on the performance of the Nigeria economy. Thus, an appreciation of the exchange rate will have a negative effect on the performance of the economy while its depreciation will have a positive influence on the economic performance.

Mauna and Reza (2001) studies the effect of trade liberalization, real exchange rate and trade diversification on selected North Africa countries Morocco, Algeria and Tunisia. By decomposing in real exchange rate into fundamental and monetary determinants, and by using both standard statistical measures of exchange rate fluctuation and the measures of exchange rate risk developed by Puree and Steiner (1989), they concluded that exchange rate depreciation has a positive effect on the quantity or manufac- 
tured exports while exchange rate misalignment, volatility or fluctuation has a negative effect.

Tharakan, (1999) and Vieira et al (2013) all ascertained that highly fluctuated exchange rate has negative impacts on economic growth but moderately volatile exchange rate has positive impacts on growth as revealed in (Tarawalie, 2010), overvalued exchange on the other hand rate reduces growth (Elbadawi and Kaltani, 2012).

However, Iuhia and Bogdan (2012) are of the view that the stability of exchange rate does not encourage economic growth especially if obtained by enormous government official interventions to sustain the exchange rate regime, similar to Harms and Kertschnman (2009). Razmi et al (2012) also discovered positive relationship between investment growth and real exchange rate undervaluation.

They further recommended that given the model employed in their research, if the presence of underemployment and over reliance on imported capital goods establishes important networks through which the economy is being affected by the real exchange rate affects, targeting the latter may be more operational in promoting capital accumulation and unemployment reduction in low income countries compared to developed countries.

Dell' Arricia (1999) examined the effect of exchange rate fluctuation on the bilateral trade of European Union members plus Switzerland over the period 1975 - 1994 using several definitions of volatility. In basic OLS regression, exchange rate fluctuation had a small but significant negative impact on trade; reducing volatility to zero in 1994 would have increased trade by an amount ranging from the ten to 13 percent, depending on the measures of fluctuation used using both fixed and random effects, the im- 
pact of fluctuation was still negative and significant but smaller in magnitude. The author found that elimination of exchange rate fluctuation would have increased trade by about 3 percent in 1994.

Accam (1997), while examining the exchange rate volatility and FDI flows in some selected 20 least developed countries, using OLS estimation, and employing standard deviation as a proxy for instability in exchange rate volatility, the result shows a significant negative relationship between exchange rate uncertainty and FDI flows for the period.

In their study, Broda and Romails (2003) found that real exchange rate volatility depresses trade in differentiated goods. The study used bilateral trade model, where the oils (ordinary least square) and GMM (Generalized method of moment) methods were used. After taking into account the direction of causality, they ascertained that a 10 percent increase in volatility depresses differentiated product trade by 0.7 percent, while a 10 percent increase in trade reduces exchange rate volatility by 0.3 percent.

Their OLS estimated results showed that the effect or volatility on trade is reduced by 70percent. They justified the result by arguing that much of the correlation between trade and change to the effect that trade has in depressing fluctuation. Their study further revealed that a 10 percent increase in the intensity of bilateral trading relationship reduces the volatility if the associated exchange rate by 0.3 percent.

Moving to the studies of exchange rate volatility on trade in LDC'S Countries (1981) who used a log-level model specification to examine Brazilian exports, used annual data for 1965-1974 to arrive at the conclusion that a significant reduction in exchange rate uncertainty in Brazilian's economy during the crawling - peg era was adopted in 1968. 
Phillips (1986), Granger and Newbold (1974) found that export and exchange rate risks are related, however, they criticize the use of a log-level model when the data is non-stationary.

Osuntogun et al (1993) in their analysis of strategic issues in promoting Nigerian non-oil exports determined the effects of exchange uncertainty on Nigerian non-oil export performance as a side analysis. This is the pioneering effort in Nigeria to determine the effect of exchange rate risk on exports. However, their model did not take into consideration the cross price effects. Exchange rate acts as shock absorber if rigidly fixed, the shocks of inflation and deflation and deflation from aboard are transmitted to internal economy systems. But variations in the exchange can wand off the invasion of the inflationary and deflationary forces. If demand and supply could work excellently in economic sense, it would be better to allow exchange rate to be freely determined by both demand and supply.

Mordi (2006) adopted GARCH model and posited that failure to properly manage exchange rates can induce distortions in consumption and production patterns and that excessive currency volatility creates risks with destabilizing effects on the economy. In the same vein, the study of Danmola (2013) analysed the impact of exchange rate volatility on Macroeconomic variables using Correlation Matrix, Ordinary Least Square (OLS) and Granger Causality test, the findings of the study showed that exchange rate volatility has a positive impact on Gross Domestic Product, Foreign Direct Investment and Trade Openness, but with negative impact on the inflationary rate in the country. Danmola then suggested that there is the need for the country to improve their revenue base. 
Conclusively, a lot of supportive studies have examined the impact of exchange rate fluctuations on trade and investment but a few has considered the impact of exchange rate fluctuation on Nigerian economic growth spanning from the Pre SAP, SAP, Post-SAP period using the historical model which is the focal point of this study.

\section{Research Methodology}

\section{Model Specification}

For the objectives of the study to be captured, a model with theoretical and empirical validity needs to be developed. The traditional method of standard deviation was adopted in line with Zubair and Jega (2008) and Gudjarati (2004) since there are few researchers that have used this approach to model exchange rate fluctuation in Nigeria for the estimation of the first objective which is the relationship between exchange rate variation and economic growth in Nigeria. To achieve this, first we need to calculate the real NairaDollar exchange rate, by taking the price differential of Nigeria to the USA so as to get a single measure of the exchange rate index.

For instance, Kyereboah-Coleman et al. (2008) utilized the method of using the Purchasing Power Parity approach to estimate the real exchange rate that was adopted. While calculating the real exchange rate, the Nominal Exchange Rate is adjusted for the price differential by keeping the US prices.

In order to capture the volatility series the standard deviation method will be used. Notably the standard deviation measure will equal zero when the exchange rate follows a constant trend. Consistently, if the exchange rate 
follows a constant trend it could be a source of exchange risk. This measure is as a benchmark proxy for exchange rate volatility.

According to Gudjarati (2004), the model is therefore derived as follows:

$S D_{t+m}=\left[\frac{1}{m} \sum_{i=1}^{m}\left(\left(\ln E X_{t+i-1}-\ln E X_{t+i-2}\right)\right)^{2}\right]^{\frac{1}{2}}$

Where $m$ is the order of moving average

To check for the impact of exchange rate fluctuation on Nigeria's economic growth which is the second objective which is to examine the effect of exchange rate fluctuation on the growth process of Nigerian economy, the model assumes an underlying relationship between some macroeconomic variables that can influence the economic growth of a nation measured as Gross Domestic Product (GDP).With regards to the merits of the Ordinary Least Square (OLS) modeling method, the multiple linear regression analysis was used with the dependent variable as Real Gross Domestic Product while the explanatory variables were real interest rate, real exchange rate, oil prices, trade openness, and Inflation Rate. We therefore present a model below relating GDP to some other macroeconomic variables.

$\mathrm{RGDP}=\gamma_{0}+\gamma_{1} \mathrm{EXRVOL}+\gamma_{2} \mathrm{EXR}+\gamma_{3} \mathrm{INF}+\gamma_{4} \mathrm{TOP}+\gamma_{5} \mathrm{OLP}+\delta_{\mathrm{t}}$

Where:

RGDP $=$ Real Gross Domestic Product

EXRVOL=Exchange Rate Volatility

$\mathrm{EXR}=$ Real Exchange Rate

TOP $=$ Trade Openness $\left(\frac{x+m}{G D P}\right)$

OLP=Oil Price

$\mathrm{INF}=$ Inflation Rate 
$\delta_{\mathrm{t}}=$ Error term

$\gamma_{0}=$ Intercept of relationship in the model/Constant term

$\gamma_{1}, \gamma_{2}, \gamma_{3}, \gamma_{4}$ and $\gamma_{5}$ are regression coefficients.

The parameter $\gamma_{1}, \gamma_{2}, \gamma_{3}, \gamma_{4}$ and $\gamma_{5}$ which are coefficient of the variables which denote the degree of change of the dependent variables (YG) as a result of a unit change of other independent variables the error term

( $\mu$ i) which is used to capture the impact of other variables that are not included in the model.

To test the existence of a significant relationship among the variables expressed in equation 2, the null and alternative hypotheses are stated as follows:

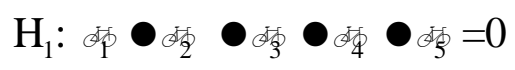

(Exchange rate fluctuation does not have a significant effect on Nigeria's economic growth).

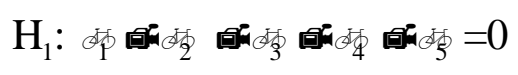

(Exchange rate fluctuation has a significant effect on Nigeria's economic growth)

\section{Assumptions and justification of the Standard Deviation Method}

The three main purposes of forecasting volatility are for risk management, for asset allocation, and for taking bets on future volatility. A large part of risk management is measuring the potential future losses of a portfolio of assets, and in order to measure these potential losses, estimates must be made of future volatilities and correlations.

Several methods like SD, MASD, variants of ARCH and GARCH and many more have been adopted by many researchers to 
proxy and estimate exchange rate volatility, but there is not still an appropriate method because they all have their shortcomings.

The simplest and most widely used approach to estimating volatility is to use historical standard deviation (Reider, 2009).

This method uses the Standard deviation of the first difference of the logarithm of the real exchange rate (EXRVOL) will be used as a proxy measure of exchange rate volatility or risk because of its simplicity, easy computation, level of understanding and time frame. A key characteristic of standard deviation as a measure is that it gives large weight to extreme volatility. The standard deviation is calculated over a one-year period, as an indicator of short-run volatility, as well as over a five-year period to capture long-run variability.

\section{Method of evaluation}

Time series econometric shall be employed, the multiple regression model that will use the ordinary least square (OLS) method because it is most popular-widely used among the variance time series econometric techniques, the best estimator, unbiased, linear and sufficient estimator.

\section{Sources of Data}

Secondary data was extracted such as the Central Bank of Nigeria statistical bulletin. The study employs quarterly Nigeria data for the period 19702013. The annual data was selected due to difficulty in data collection. 


\section{Emperical Analysis and Discussion of Results}

This section consists of empirical analysis of data used for the study, data interpretation and discussion of findings.

\section{Descriptive Statistics}

The descriptive statistics of the variables is provided in table 1 below. From the table, the averages of the variables are 12.07, 0.1, 2.07, 33.65, 19.40 and 2.280 for real gross domestic product(RGDP), exchange rate volatility (EXRVOL), trade openness (OPNX), oil price (OILP), inflation rate (INF) and exchange rate (LEXR)respectively. The maximum values of the variables are 13.76, 0.11, 9.22, 112.56, 72.80 and 5.059 for real gross domestic product(RGDP), exchange rate volatility (EXRVOL), trade openness (OPNX), oil price (OILP), inflation rate (INF) and exchange rate (LEXR)respectively while the minimum values of the variables are 8.46, $0.00,0.03,3.56,1.60$ and -0.604 for real gross domestic product(RGDP), exchange rate volatility (EXRVOL), trade openness (OPNX), oil price (OILP), inflation rate (INF) and exchange rate (LEXR)respectively. The standard deviation showed that oil price (28.07) was the most volatile variable in the time series. This is followed by inflation rate (17.8), trade openness (2.63), exchange rate (2.278) and real gross domestic product (1.45) while exchange rate volatility $(0.02)$ was the least volatile of the time series.

The skewness statistic from table below revealed that real gross domestic product (RGDP), exchange rate volatility (EXRVOL)and exchange rate (EXR)were negatively skewed while trade openness (OPNX), oil price (OILP) and inflation rate (INF) were positively skewed. The kurtosis statistics showed that exchange rate was platykurtic, suggesting that the distribu- 
tion is flat relative to normal distribution while real gross domestic product, exchange rate volatility, trade openness, oil price and inflation rate were leptokurtic, suggesting that the distribution were peaked relative to normal distribution. The Jarque-Bera statistic rejected the null hypothesis of normal distribution for all the variables (real gross domestic product (RGDP), exchange rate volatility (EXRVOL), trade openness (OPNX), oil price (OILP) and inflation rate (INF)) at five per cent critical value with exception to exchange rate. For exchange rate, the Jarque-Bera statistic could not reject the null hypothesis of normal distribution for the variable at five per cent critical value.

Table 1. Descriptive Statistics

\begin{tabular}{|l|l|l|l|l|l|l|}
\hline Variables & LRGDP & EXRVOL & OPNX & OILP & INF & LEXR \\
\hline Mean & 12.07 & 0.10 & 2.07 & 33.65 & 19.40 & 2.280 \\
\hline Median & 12.51 & 0.11 & 0.46 & 25.43 & 12.70 & 2.851 \\
\hline Maximum & 13.76 & 0.11 & 9.22 & 112.56 & 72.80 & 5.059 \\
\hline Minimum & 8.46 & 0.00 & 0.03 & 3.56 & 1.60 & -0.604 \\
\hline Std. Dev. & 1.45 & 0.02 & 2.63 & 28.07 & 17.23 & 2.278 \\
\hline Skewness & -1.19 & -2.96 & 1.26 & 1.49 & 1.57 & -0.0745 \\
\hline Kurtosis & 3.44 & 13.02 & 3.44 & 4.17 & 4.44 & 1.3518 \\
\hline Jarque-Bera & 10.46 & 242.53 & 11.70 & 18.37 & 21.30 & 4.907 \\
\hline Probability & 0.01 & 0.00 & 0.00 & 0.00 & 0.00 & 0.086 \\
\hline Observations & 43 & 43 & 43 & 43 & 43 & 43 \\
\hline
\end{tabular}

Author's computation E-views 7 (2015)

\section{Unit Root Test}

Following the descriptive statistics of the variables, this time series properties of the variables was conducted by the Augmented Dickey-Fuller (ADF) and the result presented in table 2. The Augmented Dickey Fuller (ADF) 
test showed that all the variables were integrated of order one; that is, the variables became stationary after first difference.

Table 2. Unit Root Test Result

\begin{tabular}{|l|l|l|l|}
\hline \multicolumn{5}{|c|}{ Augmented Dickey-Fuller (ADF) Test } \\
\hline Variables & Level & $1^{\text {st }}$ Diff & Status \\
\hline LRGDP & -2.4016 & $-6.0447^{*}$ & $\mathrm{I}(1)$ \\
\hline EXRVOL & -1.8993 & $-7.4973^{*}$ & $\mathrm{I}(1)$ \\
\hline OPNX & 0.6605 & $-7.9072^{*}$ & $\mathrm{I}(1)$ \\
\hline OILP & 0.9592 & $-9.6224^{*}$ & $\mathrm{I}(1)$ \\
\hline INF & -3.4616 & $-6.5747^{*}$ & $\mathrm{I}(1)$ \\
\hline EXR & -0.2166 & $-5.2530^{*}$ & $\mathrm{I}(1)$ \\
\hline
\end{tabular}

Note: * denotes one percent significance level.

Author's computation E-views 7 (2015)

\section{Co-integration Estimate}

The result of the co-integration estimate is presented in table 3 below. From table 3 , it is observed that the null hypothesis of no co-integration, for $\mathrm{r}=0$ and $\mathrm{r} \leq 1$ were rejected by both the trace and the maximum Eigen-value statistic. The statistical values of these tests were greater than their critical values. However, the null hypothesis of no co-integration for $r \leq 2$ could not be rejected by the trace and maximum Eigen-value statistics because their statistical values were less than their critical values. The implication of the cointegration estimate is that there are two co-integrating equations in the estimating model at five per cent significant level. 
Table 3. Summary of the Co-integration Estimate

\begin{tabular}{|l|l|l|l|l|l|l|l|}
\hline \multicolumn{3}{|l|}{ Trace Test } & \multicolumn{3}{|c|}{ Maximum Eigen value Test } \\
\hline Null & Alternative & Statistics & $\begin{array}{l}\mathbf{9 5 \%} \\
\text { critical } \\
\text { values }\end{array}$ & Null & Alternative & Statistics & $\begin{array}{l}\text { 95\% crit- } \\
\text { ical val- } \\
\text { ues }\end{array}$ \\
\hline $\mathrm{r}=0$ & $\mathrm{r} \geq 1$ & 73.357 & 69.819 & $\mathrm{r}=0$ & $\mathrm{r}=1$ & 40.916 & 33.877 \\
\hline $\mathrm{r} \leq 1$ & $\mathrm{r} \geq 2$ & 48.441 & 47.856 & $\mathrm{r} \leq 1$ & $\mathrm{r}=2$ & 29.799 & 27.584 \\
\hline $\mathrm{r} \leq 2$ & $\mathrm{r} \geq 3$ & 18.642 & 29.797 & $\mathrm{r} \leq 2$ & $\mathrm{r}=3$ & 11.157 & 21.132 \\
\hline $\mathrm{r} \leq 3$ & $\mathrm{r} \geq 4$ & 7.486 & 15.495 & $\mathrm{r} \leq 3$ & $\mathrm{r}=4$ & 7.485 & 14.265 \\
\hline
\end{tabular}

Author's computation E-views 7 (2015)

Long Run Regression Estimate on the impact of Exchange Rate Volatility on Economic Growth in Nigeria

The long run regression estimate of the impact of exchange rate volatility on economic growth in Nigeria from 1970 to 2014 is presented on table 4 below. The coefficient of determination (that is $\mathrm{R}^{2}$ ) showed that the explanatory variables jointly explained about 78 per cent of variations in unemployment rate in Nigeria during the study period. The F-statistics (26.95; $\mathrm{p}<0.05)$ showed that the model estimated is appropriate while the Durbin Watson statistics is 1.80 , indicating the absence of serial auto-correlation in the long run estimate.

The long run estimate presented on table 4 below showed that exchange rate volatility (EXRVOL)had a positive (11.90) and insignificant impact on economic growth in Nigeria, suggesting that fluctuations in exchange rate had no significant influence on economic growth in Nigeria. Trade openness (OPNX) had a negative (-0.37) and significant effect on economic growth, suggesting that a one percent decrease in trade openness will enhance economic growth by about 37.1 per cent. Also, international 
oil price (OILP) was observed to having a positive (0.029) and significant impact on economic growth, suggesting that a one percent increase in oil price will enhance economic growth by about 2.9 percent. In contrast to the positive and significant impact of international oil price on economic growth in Nigeria, it was observed that inflation rate (INF) had a positive (0.008) and insignificant impact on economic growth in Nigeria, suggesting that inflation rate had no significant influence on economic growth in Nigeria during the study period. In contrast to the insignificant impact of exchange rate volatility on economic growth in Nigeria, it was observed that exchange rate (EXR) had a positive (0.65) and significant impact on economic growth in Nigeria, suggesting that a one per cent increase in exchange rate will promote economic growth by about 65.2 per cent.

With respect to the focus of study on the impact of exchange rate volatility on economic growth in Nigeria, the regression estimate showed volatility in exchange rate had no influence on economic growth while it is actual exchange rate that had positive effect on economic growth in Nigeria in the long run.

Table 4. Long Run Regression Estimate

Variable Coefficient Std. Error t-Statistic Prob.

\begin{tabular}{lllll}
\hline \hline C & & & & \\
EXRVOL & 11.89671 & 6.127694 & 1.941466 & 0.0598 \\
OPNX & -0.371380 & 0.121484 & -3.057023 & 0.0041 \\
OILP & 0.028813 & 0.008785 & 3.279620 & 0.0023 \\
INF & 0.007939 & 0.007081 & 1.121182 & 0.2694 \\
LEXR & 0.652061 & 0.092198 & 7.072423 & 0.0000 \\
\hline \hline
\end{tabular}


R-squared

Adjusted R-squared

S.E. of regression

Sum squared resid

Log likelihood

F-statistic

Prob(F-statistic)
0.784580

0.755470

0.715021

18.91644

$-43.35922$

26.95156

0.000000
Mean dependent var

S.D. dependent var

Akaike info criterion

Schwarz criterion

Hannan-Quinn criter.

Durbin-Watson stat
12.06574

1.445947

2.295778

2.541527

2.386402

1.805369

Author's computation E-views 7 (2015)

Short Run Regression Estimate on the impact of Exchange Rate Volatility on Economic growth in Nigeria

The short run relationship between exchange rate volatility and economic growth is examined below. Prior to the short run regression estimate, the stationarity property of the residual from the long run estimate is examined and the result is presented on table 5 below. Using the Augmented Dickey Fuller (ADF) test, the stationarity test showed that the residual is integrated of order one at five per cent significant level.

Table 5. Residual Stationarity Test

\begin{tabular}{|l|l|l|}
\hline Variable & ADF Test & Order of Integration \\
\hline Resid & $-3.4879^{*}$ & $\mathrm{I}(0)$ \\
\hline
\end{tabular}

Note: * implies $1 \%$ significance level.

Author's computation E-views 7 (2015)

With respect to the parsimonious regression estimate capturing the short run analysis, it is observed from table 6 that the coefficient of determination (that is $\mathrm{R}^{2}$ ) from the short estimate showed that the explanatory variables jointly explained about 60 per cent of variations in economic growth in Nigeria. The F-statistics $(15.01 ; \mathrm{p}<0.000)$ showed that the model estimated is appropriate while the Durbin Watson statistics is 1.98 , indicating the 
absence of serial auto-correlation in the long run estimate. The short run regression estimate also showed that the coefficient of the error-term for the ECM model is both statistically significant at five per cent and negative. The coefficient estimate of the error correction term of -0.24 implied that the model corrects its short run disequilibrium by about 24.1 per cent speed of adjustment in order to return to the long run equilibrium. Also, the negative sign of the error correction term indicates a move back towards equilibrium.

In addition to the above, it was observed that only the coefficients of the currents values of trade openness (DOPNX) and inflation rate (DINF) have significant effect on economic growth in the short run. Specifically, current trade openness had a negative $(-0.17)$ and significant effect on economic growth, suggesting that a one percent decrease in trade openness will enhance economic growth by about 17 per cent in the long run. For inflation rate, it was observed that the variables had positive (0.008) and significant impact on economic growth in Nigeria, suggesting that a one percent increase in inflation rate will promote economic growth by 0.8 percent in the short run. The remaining variables in the short run estimate presented in table 6, had insignificant effect on economic growth in the short run.

With respect to the objective of this study, it was observed from the discussion on the short run analysis that exchange rate volatility had no significant effect on economic growth in the short run. 
Table 6. Parsimonious Short Run Regression Estimate

Variable

Coefficient Std. Error t-Statistic Prob.

\begin{tabular}{lllll}
\hline \hline ECM1(-1) & -0.240539 & 0.108108 & -2.224992 & 0.0343 \\
DLRGDP(-2) & -0.204337 & 0.174832 & -1.168760 & 0.2524 \\
DERVOL & 0.002473 & 0.001789 & 1.382529 & 0.1777 \\
DOPNX & -0.168356 & 0.085825 & -1.961618 & 0.0498 \\
DOPNX(-2) & -0.141164 & 0.100666 & -1.402301 & 0.1718 \\
DINF & 0.008415 & 0.004068 & 2.068613 & 0.0479 \\
DINF(-2) & 0.006296 & 0.004090 & 1.539342 & 0.1349 \\
DLEXR & 0.137827 & 0.209196 & 0.658839 & 0.5154 \\
DLEXR(-2) & -0.561677 & 0.326446 & -1.720583 & 0.0964 \\
C & 0.294680 & 0.091144 & 3.233121 & 0.0031 \\
\hline \hline & & & & \\
R-squared & 0.603080 & Mean dependent var & 0.129675 \\
Adjusted R-squared & 0.526790 & S.D. dependent var & 0.339526 \\
S.E. of regression & 0.317272 & Akaike info criterion & 0.785213 \\
Sum squared resid & 2.818531 & Schwarz criterion & 1.291877 \\
Log likelihood & -3.704266 & Hannan-Quinn criter. & 0.968407 \\
F-statistic & 15.014802 & Durbin-Watson stat & 1.979483 \\
Prob(F-statistic) & 0.001425 & & \\
\hline \hline
\end{tabular}

Author's computation E-views 7 (2015)

\section{Summary of findings}

With respect to the objective of this study, it was observed from the discussion on the short run analysis that exchange rate volatility had no significant effect on economic growth in the short run.

The Augmented Dickey Fuller (ADF) test showed that all the variables were integrated of order one; that is, the variables became stationary 
after first difference. Furthermore, the implication of the co-integration estimate is that there are two co-integrating equations in the estimating model at five per cent significant level. The result of the long run regression estimates depicted by the $\mathrm{R}^{2}$ (coefficient of determination) showed that the explanatory variables jointly explained about 78 per cent of variations in exchange rate of Nigeria during the study period. Furthermore, the long run estimate equally showed that exchange rate volatility (EXRVOL) had a positive (11.90) and insignificant impact on economic growth in Nigeria, suggesting that there was no significant influence of exchange rate fluctuation on economic growth in Nigeria. Evidently, the results show that Inflation rate had no significant influence on economic growth in Nigeria during the study period. It was observed that exchange rate (EXR) had a positive (0.65) and significant impact on economic growth in Nigeria, suggesting that a one per cent increase in exchange rate will promote economic growth by about 65.2 per cent. Over and above all, the value of the International oil price (OILP) was observed to have a positive (0.029) and significant impact on economic growth, suggesting that a one percent increase in oil price will enhance economic growth by about 2.9 percent.

\section{Conclusion}

In conclusion, this research work assessed the impact exchange rate fluctuation on Nigerian economic growth using the traditional approach of standard deviation which helped estimate the Volatility persistence and asymmetric properties for the Nigerian foreign exchange market. The impact of exchange rate fluctuation on Nigerian economic growth was investigated by 
incorporating the calculated volatility of exchange rates for the study period in the regression model.

The objective of the study was to measure the impact of exchange rate fluctuation on economic growth in Nigeria both in the long and short run. It was established that there is a link between exchange rate fluctuation and economic growth in Nigeria in both the long and short run. The regression estimate showed that volatility in exchange rate had no influence on economic growth while its actual exchange rate had positive effect on economic growth in Nigeria in the long run.

This study established that there is a positive but insignificant relationship between economic growth and exchange rate fluctuation in the short run. The aforementioned outcome was consistent with the earlier study of Danmola (2013).

Empirically, the insignificant positive relationship between exchange rate fluctuation and economic growth was attributed to the influence of the monetary authorities in mitigating exchange rate fluctuation in Nigeria. Observably, the high volatility persistence and its significant impact on the Nigerian economy of oil prices could have been due to OPEC's regulations, global recession or change in the structure of the Nigerian economy since Nigeria's foreign exchange earnings are more than 90 per cent dependent on receipts from crude oil Export.

Further research work can be done on the impact of Central Bank regulation on exchange rate volatility in Nigeria. 


\section{Policy Implications}

This study's findings from the policy perspective are helpful to policy makers, government and monetary authorities since the exchange rate as an economic indicator is significant to achieving economic growth and development. Based on the findings of this study, it was therefore recommended that:

(i) There should be an increase in the exchange rate of Naira in order to enhance economic growth.

(ii) The Nigerian government should endeavour to stabilize the exchange rate of Naira in order to achieve economic growth because of the current high fluctuation of naira exchange value.

(iii) Investors should consider fluctuations in other macroeconomic variables rather than fluctuation in the exchange rate market to guide their decisions in order to ascertain where to direct investments for profit maximization.

(iv) The Nigerian economy need be diversified to enhance economic growth.

(v) The government should encourage domestic production and consumption of goods and services in order to curtail the effects of exchange rate fluctuation on other macroeconomic variables.

(vi) Oil price should be stabilized since it was the most volatile variable during the years of study in order to ensure economic growth in Nigeria.

(vii)Lastly, to maintain and sustain exchange rate and economic stability, more attention need be paid by the government to other 
more volatile macroeconomic variables like oil price and inflation rate in Nigeria.

\section{Limitation of the study}

Despite the salient findings of the study, it still has some lapses which among others include:

i. Building adequate exchange rate modeling and forecasting from the end of the central bank is lacking

ii. Failure to incorporate the effect of asset prices in domestic monetary policy activities which in turn could help to improve transparency and functioning of the foreign exchange market at large.

iii. The use of standard deviation where exchange rate volatility is measured according to the degree to which exchange rate fluctuates in relation to its mean overtime. The challenges of using this method can be summarized in to two folds namely; first that it assumes that, the empirical distribution of the exchange rate is normal. Second, that it does not reflect the distribution between unpredictable components of the exchange rate process hence failing to capture the past information of the exchange rate according to Mehrotra (2013).

Over and above all, the limitation of this study is in area of accessing some key important variables due to lack of consistency, where different data source gives different data for the same variable. Hence to maintain accuracy and consistency the study sourced of such from international sources like from World Development Indicators (WDI) 


\section{References}

1. Adeoye, B.W and Atanda, A.A (2012). "Exchange rate volatility in Nigeria: Consistency, Persistency and severity analyses" CBN Journal: 29-49.

2. Adler, M. and Lehman, B., (1983). "Deviations from purchasing power parity in the long run,"Journal of Finance, 38(5),1471-487

3. Adu-Gyamfi, A. (2011). "Assessing The Impact of Exchange Rate Volatility on Economic Growth in Ghana" Unpublished master's thesis submitted to the Department of Economics Kwame Nkrumah University of Science and Technology.

4. Afolabi L. (2005). Theory of Monetary Economics, Ibadan: University Press Ltd.

5. Ajakaiye, O. (2001), "Impact of Exchange Rate Depreciation on Sectorial Prices" NISER Monograph Series, $(1986-2000)$.

6. Ajakaiye D. (2002). Economic Development in Nigeria: A Review of Experience, CBN Bullion, Vol. 26 pp4664. CBN Annual Reports of Accounts (various Issues) 200 - 212

7. Akanbi, P.A. and Adeyeye, T.C. (2010). "Impact Of Global Financial Crisis On Nigerian Economy: A Critical Approach' 'Journal of Business and Organizational Development Vol.2 pgl13

8. Akonji, D. R. (2013).“The Impact of Exchange Rate Volatility on the Macro Economic Variables in Nigeria”. European Scientific Journal. 9(7), 152-165.

9. Akpan E.O. and Johnson A.A, (2011): Effects of Exchange Rate Movements on Economic Growth in Nigeria. CBN Journal of Applied Statistics, 2(2), 1-35

10. Alawin M., Sawie K., Al-omar I., Al-hamdi M., (2013). "Econometric Analysis for the Impact of the Real Effective Exchange Rate on the Jordanian Economy', European Scientific Journal September, 9, 212-225.

11. Asinya, F. A. and Takon, N. (2014). "Exchange rate depreciation and government policy is Nigeria: An Empirical Evidence”. The Business and Management Review. 4(3), 161-170.

12. Ayodeji R. and Olowe, A. (2009). "Modelling Naira/Dollar Exchange Rate Volatility: Application Of Garch And Assymetric Models". International Review of Business Research Papers, 5, 337-358.

13. Bacchetta, P. and van Wincoop, E. (2003). "Why do Consumer Prices React Less than Import Prices to Exchange Rates?” Journal of European Economic Association, 1, 662-670.

14. Bakare, A.S.,(2009). "The Exchange Rate Determination in Nigeria: The Purchasing Power Parity Option" Mathematical Theory and Modeling www.iiste.org pg 45

15. Central Bank of Nigeria (CBN) (2006). "Statistical Bulletin", Annual Publication of the Central Bank of Nigeria. 
16. Central Bank of Nigeria (CBN) (2006). "Annual Report and Statement of Account", Annual Publication of the Central Bank of Nigeria, CBN Economic and Financial Review, 29(2).

17. Chen, J. (2012). Real exchange rate and economic growth: evidence from Chinese provincial data (1992 - 2008), Paris School of Economics Working Paper, No. 5.

18. Copeland, L., (1989). Exchange rates and international finance, University of Manchester Institute of Science and Technology, Wokingham, England: Addison-Wesley publishing company Inc.

19. Cote, A., (1994). Exchange rate volatility and trade: A survey, Working Paper 94-5, Bank of Canada.

20. Danmola, R.A (2013). "The Impact of Exchange Rate Volatility on The Macro Economic Variables in Nigeria" European Scientific Journal, 9, 579

21. Davarajan, S. (1993). "External shocks, Purchasing Power Parity and the Equilibrium Real exchange Rate," The World Bank Economic Review. 7(1), 45-63.

22. David O., Umeh I.C and Ameh A.A (2010). "The Effect of Exchange Rate Fluctuations on the Nigerian Manufacturing Sector”. African Journal of Business Management, 4(14), 1-22.

23. Dell' Ariccia, G. (1999). "Exchange Rate Fluctuations and Trade Flows: Evidence from the European Union" IMF Staff papers, 46(3), 315-34.

24. Dickey, D. A. and Fuller, W. A. (1981). "Likelihood Ratio Tests for Autoregressive Time Series with a Unit Root", Econometrica, 49, 1057 - 1072.

25. Douglas, G. O. and Jike, V. T. (2005). "Policy Reforms and Manufacturing Exports in Nigeria", Paper Presented at the 2005 Nigeria Economic Society (NES) National Conference.

26. Dornbusch, R. (1988). Open macroeconomics, 2nd Edition, New York.

27. Adetifa, S. (2003). International Business Finance in Nigeria, Ikeja Lagos, McBay Publishers.

28. Edwards, S., (1989). "Exchange rate misalignment in developing countries," National Bureau of Economic Research (NBER) Working Paper Series, No.2950, April, Oxford University Press.

29. Engel, R. F. and C. W. J. Granger (1987). "Cointegration and error correction: Representation, estimation and testing". Econometrica, 55. 251 -276

30. Engle, R. F. (2003). "Risk and Volatility: Econometric Models and Financial Practice", Nobel Lecture, 8, 2003.

31. Frenkel, J. A. (1978). "Purchasing Power Parity: Doctrinal Perspective and Evidence from the 1920s." Journal of International Economics, 8(2), 169-91.

32. Frenkel, R., and Taylor L (2006). Real exchange rate, monetary policy and employment, United Nations, New York, Desa Working paper n.19

33. Greene, W. H. (2003). Econometric Analysis ( New York: Prentice Hall), 5th Edition 
34. Guitan, M. (1976). "The Effects of Changes in exchange Rate on Output, Prices and The balance of Payments,"Journal of International Economics, 6, 65-74.

35. Gujarati DN (2005). Basic Economics, McGraw-Hill, India, 5th Edition.pg 89

36. Jhingan, M. L. (1997). Macroeconomic Theory, Vrinda Publications Ltd, Delhi, pg. 697.

37. Jhingan M. L. (2004). Money, Banking, International Trade and Public Finance, New Delhi: Vrinda Publications Ltd. pg 225

38. Johansen, S. and Juselius, K. (1990). "Maximum Likelihood Estimation and Inference on Cointegration with Applications to the Demand for Money", Oxford Bulletin of Economics and Statistics, 52, $169-210$.

39. Kamin, Steven B., and Marc Klau. (1998). "Some Multi-country Evidence on the Effects of Real Exchange Rates on Output.” International Finance Discussion Papers, no. 611. Washington, D.C.: Federal Reserve Board.

40. Kamin, Steven B., and John H. Rogers. (1997). "Output and the Real Exchange Rate in Developing Countries: An Application to Mexico." International Finance Discussion Paper, no. 580. Washington, D.C.: Federal Reserve Board.

41. Koutsoyianis, A. (1993). Theory of Econometrics, Second Edition.

42. Lothian, J. and Taylor, M., 1997. "Real exchange rate behavior," Journal of International Money and Finance, 116(6), 945-954.

43. McKinnon, R. (1963). Optimum Currency Areas,“ American Economic Review” 53, 717-725.

44. Mohanty, M. S. and Klau M. (2004). "Monetary Policy Rules in Emerging Market Economies: Issues and Evidence". Bank of International Settlements Working Papers, No. 149.

45. Mordi, N. O. (2003, 2006), "Challenges of Exchange Rate Volatility in Economic Management in Nigeria", In The Dynamics of Exchange Rate in Nigeria, Central Bank of Nigeria Bullion, 30(3), 17-25.

46. Mundell, Robert, (1961). “A Theory of Optimal Currency Areas”. American Economic Review 51, 657-665.

47. Musyok,D., Pokhariya, G., P, and Pundo, M., (2012). "The impact of real exchange rate volatility on economic growth: Kenyan evidence" BEH - Business and Economic Horizons, 7, 59-75

48. Obandan, M. I (1993). Overview of Nigeria's Exchange rate Policy and Management. Lagos: C.B.N Publications.pg 22-34

49. Obadan MI (1994). "Nigeria's Exchange RATE Policy and Management" National Centre for Economic Management and Administration (NCEMA) Monographs Series. No.5, NCEMA Publication, Ibadan

50. Obadan, M. I. (2006), "Overview of Exchange Rate Management in Nigeria from 1986 to Date", In The Dynamics of Exchange Rate in Nigeria, Central Bank of Nigeria Bullion, 30(3), 1-9. 
51. Ojo MO (1990). The Management of Foreign Exchange Resources in Nigeria CBN Economic and Financial Review, 28(3).

52. Olisadebe EU (1991). "Appraisal of Recent Exchange Rate Policy Measures in Nigeria”.

53. Opaluwa D (2008). "The Effect of Exchange Rate Fluctuations on the Nigerian Manufacturing Sector 1986-2005". An M.Sc Thesis Presented to the Department of Economics, Benue State University, Makurdi.

54. Osigwe A. C. (2015). "Exchange Rate Fluctuations, Oil Prices and Economic Performance: Empirical Evidence from Nigeria”' International Journal of Energy Economics and Policy

55. Oyejide T.A, Ogun O. (1995). "Structural Adjustment Programme and Exchange Rate Policy" in Macroeconomic Policy Issues in an Open Developing Economy: A case study of Nigeria. NCEMA Publications, Ibadan.

56. Sanusi, J. O. (2004). "Exchange Rate Mechanism: The Current Nigerian Experience.Paper Presented At A Luncheon Organised By Nigerian-British Chamber of Commerce.

57. Tharakan, J. (1999), "Economic Growth and Exchange Rate Uncertainty", Applied Economics, 31(3), 347-358

58. Udoji J. (1999): Which Way Nigeria? ; Selected Speeches: arranged by Patrick Adibe: Spectrum books limited Ibadan, Nigeria. Pg 226

59. Vieira, F.V., Holland, M., da Silva, C.G., \& Bottecchia, L.C. (2013), "Growth and Exchange Rate Volatility: A Panel Data Analysis", Applied Economics, 45(26), 3733-3741 